\title{
COSTUMING FOR AFRICAN VALUES: A RE- ASSESSMENT OF UN-AFRICAN IDEALS IN CALABAR CARNIVAL
}

\author{
Rowland C. Amaefula \& Bernard Eze-Orji \\ http://dx.doi.org/10.4314/og.v12i s1.12
}

\begin{abstract}
It is a truism that indigenous theatre performances are an expression of the culture of their host community. Like a trademark, the culture on display is an irremovable part of the communal identity. However, as the community makes contact with other cultures, they adopt, adapt and appropriate such cultures to suit theirs without mortgaging their values. This is the case of carnival arts in Nigeria. The Calabar Carnival - a brainchild of the Donald Duke administration in Cross River state of Nigeria - emerged on the Nigerian performance space in the eve of the millennium. Being a performance that thrives on exhibition of culture and parade of outfits, costume becomes of the essence. The thrust of this research, therefore, is to examine the costumes used in Calabar Carnival parade. Employing the qualitative methodology, it was observed that certain costume patterns of the performers violate African values. Much as the carnival art is an imported brand of entertainment, the injection of nudity in the art is un-African. Thus, this study emphasizes the need to adapt all imported cultures to suit the beliefs and attitudes of the host community. Foreigners who perform in the Calabar Carnival, for example, should be costumed to reflect the culture of the Cross Riverians. By so doing, African values would be deepened and exported to the global stage.
\end{abstract}

\section{Introduction}

The clothing that an actor wears when he comes upon the stage to play his part, is his costume. It is not his own dress; it is the dress of the character he is representing... the costume of the actor is the 
translation into theatrical terms of the dress of everyday life (Gasner 390).

Costume and dress are distinct terms of interchangeable linguistic use. Practically, they also serve the same basic purpose but in different circumstances. While costume is a tool of disguise used by an actor to enhance characterization, dress refers to the everyday clothings and apparels deployed by man for utilitarian purposes. For clarity, Umukoro informs that,

Not only does dress serve the purpose of denoting its functional aspects, nationality or ethnic affiliations, but also evidently serves to personify its wearer by incorporating various attributes that combine to characterize his or uniqueness. Such attributes include gender, age, status, economic situation and even such abstract concepts as feeling and mood (48).

The foregoing stresses the capacity of dress to individualize a person just as costumes define an actor in drama.

The most distinguishing element prevalent in Nigerian drama is the traditional costume. Similarly, in an indigenous theatre performance such as the carnival art, the performer is costumed to reflect the values that are in harmony with his or her ethnic group. This explains why different Local Government Areas of Cross River state are decked in specific ways during the Calabar Carnival parade. Like a trademark therefore, the costume on display forms the basis of the people's identity.

Costume is culture-sensitive. While acknowledging that when different cultures interact, they tend to appropriate certain values from one another, the present paper seeks to examine unAfrican costume practices prevalent in Calabar carnival. This study has become necessary especially as the nude performers that were featured in the 2013 edition of Calabar Carnival generated immense public criticism. Therefore, the present researchers subject to interrogation costumes that violate African values in Calabar carnival. By so doing, indigenous theatre performances and, indeed, 
Calabar carnival, shall be justified as a site for deepening African values.

\section{History of Carnival}

The exact origin of modern day carnival is speculative. However, contemporary research experience locates its roots in primitive festivals honouring the beginning of a new year and the rebirth of nature. Much like the merrymaking and festivity that characterize the last days of the Lenten season in the Catholic doctrine, the carnival art emphasizes conviviality. In recent times, carnival has assumed an eclectic thrust. Thus, it has incorporated the varying cultures of different towns, cities and countries thereby commanding tourist attraction across transnational divides. Carnival is a secular popular art with global presence. It is also a major means of economic boost. The Rio Carnival, Notting Hill Carnival, Trinidad Carnival, Eyo (Lagos) Masquerade Festival/Carnival, Calabar Carnival, CarnRiv and the Abuja Carnival etc serve as a source of income to their host states while projecting their cultural values.

Spectacle is the crux of street party. That is, carnival thrives on elaborate costumes, elegance, gaiety, pageant and choreography. These elements are harmonized into a visual vision that is consistent with the worldview of the host. This is a playful way of elevating one's values the global stage. According to Asigbo, carnival is ".... form of all fool's day, where people are granted leave to poke fun at all societal institutions and dress outrageously to catch fun" (5).

However outrageous, costumes have communal connotations. The Rio and the Trinidad Carnival for example emerged from the entry of the French planters and African Slaves to the island. The French brought the principles of carnival (along with their culture and customs) in the form of "elaborate masquerade balls, house-to-house visiting and street promenading in carriages or on foot' (Lee cited in Nurse 3). Carnival was confined exclusively for the upper classes during this period and often took place as a series of festivities during the pre-Lenten Mardi Gras (Tompsett 6).

Banned from the festivities of the elite, the African slaves held their own celebrations - slaves masqueraded as their master or mistress satirizing their behaviour through performance, whilst incorporating African traditions, rituals and folklore (Pearse 19). 
With the abolition of slave tradein 1838, the African slaves took to the streets of Trinidad celebrating their emancipation in a carnivalesque style. The ex-slaves acted out the Canboulay '(cannesbrulées or burnt cane)' a torchlight procession which incorporated many of their African ritual and masquerade traditions that were said to be born out of the secret societies and religious cultures of West Africa: masking, singing, drumming and dancing. Canboulay (which re-enacts the burning of sugar cane fields by rebellious slaves) became implanted into the Mardi Gras Carnival celebrations, of the white elite, by the ex-slaves, which led to the elite abandoning the celebrations after emancipation (Dawson 6). Nurse (29) describes the post-emancipation carnival as, "...an annual ritual of social protest and resistance by the African population against the hegemony of the European elite."

This Carnival was not only a celebration of freedom but also a public expression - through cultural and artistic forms - of political opposition against the sufferings of slavery (Schechner2004). Carnival highlighted the new status of slaves within the Island (Plantation) and offered them an opportunity to broadcast that they were no longer the outcast but equals to those that once ruled them. After emancipation there were repeat attempts to ban Carnival by the authorities and control practices within (Tompsett88). Carnival continued to grow despite this resistance and eventually became accepted by the European colonial powers leading into the 20th century. The contemporary Carnival as we know today serves the cultural complexities of the island through incorporating the cultural styles and customs of the Spanish and English colonial powers, French planters, African slaves, Indian indentured labourers, and the many other ethnic groups that have settled in the brave New-World; through music, dance and masquerade (Schechner 20).

However, carnival has since divorced itself of the colonial 'otherness' and has acquired more divergent attention for scholars in such areas as carnival themes, aesthetics, technology and design, costume and cultural values are incorporated into the float. These areas have attracted scholarly research in recent times especially in Nigeria where carnival has become a new festival. This essay therefore, has taken up the Calabar Carnival costumes, an aspect of the performance aesthetics of the carnival to x-ray whether it reflects African cultural value system or not. This is following its global 
appeal and the incorporation of foreigners as tourists who partake as members of this street art. Itis therefore, believed that when a culture is exposed, it becomes bastardized and compromised and when it is imported or borrowed, it is cannibalized and expropriated to suit the need and taste of the new owner. On this note, the researchers are of the opinion that costumes worn in Calabar Carnival, though a borrowed culture has become compromised and more nudity has been given prominence in the cause of the celebration especially by foreign participants and even the natives, and therefore, do not reflect African cultural values. Carnival is like a mirror through which cultural life style of the natives reflect, refract and are exported.

\section{Calabar Carnival in Perspective}

Efforts channeled in the areas of cultural tourism in Nigeria, have yielded returns as a number of states of the Federation have recently developed carnivals in which they showcase aspects of Nigerian and popular cultural values in street performances. Cross River State, Rivers State, Lagos State, and the Federal Capital Territory-Abuja are the forerunners of this initiative. Carnival in Cross River State is probably more popular than the rest, judging from the organization, publicity, patronage, utilitarian thrust, artistic and aesthetics appealof the carnival.

Calabar Carnival also known as Carnival Calabar is an offshoot of the yearly Christmas festivities that ushered in the new millennium, 2000, by the then Cross River State governor, Mr. Donald Duke termed Calabar Festivals. This brand and change in nomenclature was as a result of the global awareness created by the festival in its yearly outings and by 2005, Carnival Calabar was added to the 30 days celebration of life, culture, cuisines, costumes and masquerades of the peoples of Cross River. Asekong and Ekpeyong have revealed the beginnings of the Carnival which took off as part of the annual Christmas festival.

The Calabar carnival with the brand name Carnival Calabar, dubbed 'Africa's Biggest Street Party' by its organizers has been held annually every 26th and 27th December since 2005. The idea of the carnival had been on the drawing board since 2000 when the 
Cross River State government started celebrating the annual Christmas festival now renamed Calabar Festival (290).

That Carnival Calabar is designed from the already established Trinidad and Tobago models, especially in the formation of registered bands that participate in the event. In 2005, five bands identified as Bayside, Freedom, Master Blaster, Passion 4 and Seagull were part of the carnival and havesince transformed beyond mere bands of cantata to evolve into platforms for cultural and intercultural displays of societal values. Each of these bands has its leader and membership drawn from the public while sponsorship is from individuals, corporate organizations like the banks, multinational companies etc. Organization in Carnival Calabar, has witnessed expertise cutting across professionals. Esekong et al elaborate thus:

In terms of organization, the carnival held every $26^{\text {th }}$ and 27 th December is run by a commission made up of technically competent members who are either drawn from the performing and visual art industry/academia or are connoisseurs of the arts. The commission also collaborates with and draws technical manpower from the well-established carnivals of Trinidad and Tobago and Rio in Brazil. As part of technical manpower development for Carnival Calabar, workshops and series of interactive sessions have been held over the years for creative personnel involved in costume production, float construction, headgear production and other technical activities. In 2012, a detachment of a band from Brazil participated in Carnival Calabar probably to strengthen the technical partnership, while also providing a different variety of cultural performance (21).

Similarly, the Carnival Calabar is divided into children carnival and adult or main carnival. Children's carnival is a vital preliminary component of Carnival Calabar. Prior to the main carnival, children, 
divided into bands, parade a short distance with colourful costumes and dance. The involvement of children is to ensure that the carnival tradition is passed on to succeeding generations and inculcate in the young minds the African value system. The main carnival procession moves through a 12-kilometre route in the city of Calabar, and is very competitive. This parade consists of registered bands, foreign participants and tourists, dignitaries, state executives, corporate entities and cultural groups from various states in Nigeria and resident communities in Cross River State who are dressed opulently and weirdly to showcase the rich cultures of Nigeria and the visiting cultures.

\section{Carnival Calabar Costume}

Carnival Calabar costume is opulently eclectic and richly dynamic. In fact, the significance of costume in carnival festivals can never be quantified. Invariably, it means there cannot be a carnival without a corresponding costume. Utoh- Ezeajugh defines costume as: ... the items of clothing, accessories and ornamentation worn by the actor or actress for the purpose of defining character and establishing the circumstances of the character's existence, by situating him/her in time and space (130).

Beyond aesthetic value of costumes, Utoh-Ezeajugh, citing Russell, describes costumes as "the moving scenery of a production, and when worn by the actors, who are the centre of all dramatic action, they are the strongest element of the visual scene; they project personality and individual emotion and obtain the strongest audience focus" (132). Carnival, a costumed street party, is a centre of attraction and the spectacular costumes serve as cynosure to both participants and audience.

In order to put a carnival band together, it takes many weeks of welding; sewing; gluing; applying feathers, sequins, foil papers, glitter and lots of creativity, energy, and patience. The first step is to come up with a theme or overall concept for the band and to develop costume illustrations for each section of dancers and revelers. Costumes are then sewn, decorated, and fitted to each individual dancer. All this creative activity takes place in what are referred to in the Caribbean as "mas camps," where teamwork and organization are crucial to creating an award-winning production. 
The larger costumes and floats are usually more difficult to design and build. Huge frames are created by bending wire into shapes, then covering with paper mâché, foam, and other materials. Physics play an important role, as the costume must be able to move and dance across stages and streets, and not fall apart! Many different forms of decorations and materials (natural and man-made) are used to transform the costume into a dream of the mind's eye.

Carnival traditions also borrow from the African tradition of putting together natural objects (bones, grasses, beads, shells, fabric) to create a piece of sculpture, a mask, or costume - with each object or combination of objects representing a certain idea or spiritual force.Feathers have become major resource in designing and creating carnival Calabar costumes. This is visible in all the registered band members, dancers, foreign participants as well as revelers who are dressed in anything opulent and weird and conversely promoting indecency.

One major setback in the Carnival Calabar costumes however, is in the area of foreign influence vis-à-vis the African cultural value systems which it should project as an African nay Nigerian brand. The costumes worn by most foreign participants and even the natives have become a major concern to traditional institutions and the general public. It has become necessary to address the situation since carnival Calabar has become a global brand due to its cosmopolitan appeal.One is jolted to this reality in the wake of the 6.0 magnitude earthquake on $30^{\text {th }}$ May in faraway Malaysia blamed on three tourists led by Elanor Hawkins and her siblings who posed nude on a sacred Malaysian mountain of Kinabalu. After being jailed for three days and fined 1000 pounds, they pleaded guilty to "...obscene act in a public place to the annoyance of others..." (Dawson 13). Their lawyer however, arguedthey were ignorant of the customs of these people. The offence has been committed, and to question tradition is a sacrilege and the consequence is the earthquake that devastated a whole nation because of the revelry of four people. Effort should be geared towards avoiding such a disaster following indecent costuming in carnival Calabar, by encouraging dress codes that reflect African cultural values. 


\section{Designing to Reflect African Values in Carnival Calabar Costumes}

African cultures have been known to scrutinize their contact with foreign cultures, accepting, rejecting, and appropriating practices and artifacts according to their needs, while still maintaining an underlying loyalty to their indigenous processes. This tradition can be applied in the case of carnival Calabar. An imported culture no doubt, but which has become an intricate part of our social existence and cultural lifestyle and yet has robbed off negatively on our ways life. Okoye in Jewsiewicki opines that:

The division of culture into two poles - modernity and tradition, separated by colonial conquest sidesteps the problems of appropriation - of Africa's cultural and intellectual cannibalization of the West (19).

Contact with foreign cultures can be tempting to the extent that the natal culture attempts to dominate at the end. This seems to be the fate of Carnival Calabar in the wake of the influence of foreign costumes on parade. Since every year's Carnival Calabar has a theme and sub-themes guiding the designs for the floats, songs, dances and costumes, it is the belief of the researchers that strict compliance with the themes should be followed to the letter, at least in a bid to forestall the incidences of pseudo-Calabar costuming.

Cross River is blessed with disparate entities and yet bound together in culture and social life style. In the mountainous north, there is Obudu (where the Cattle Ranch and international mountain race has been established as a tourist destination); in the rainforest central, there is Yakurr, (Lebokun new yam festival has become an international event); in Calabar Metropolis, there are several tourist sites. These are a major advantage in designing costumes for the Carnival Calabar. These communities should be strictly represented with costumes from their local crafts and trades during parade. This would help deepen African values and export it to foreigners who would be made to wear the native Cross River attire as part of the carnival costume themes and sub-themes which include: 
"Sustaining Earth's Treasures through our Culture";"CColours of Our Heritage";"Images of our Heritage: Yesterday, Today and Tomorrow";"Land of Our Birth: Our People, OurHeritage"; "Cross River State, the People's Paradise" (Float theme/description) in 2009; Our Strength, Our Resilience, The Bedrock of Our Future"; "The Family: Strength of Ebony" (Float theme/description) in 2010; "Processing Nature: Harmony between Man \&Nature (Float theme/description) in 2011; "Celebrating a New Dawn" (Esekong, et al, 29).

With these varied themes, sub-themes and float themes and descriptions, no reveler, participant and dancer would be allowed to costume outside the projection of the themes of the carnival. In Ugep, Yakurr local government area of the state, Leboku new yam festival has taken such a gigantic dimension and international tourist acclaim that it has become an export for the state. The costumes worn by the maidens during the Lebokun new yam festival; the iconic metal springs around them formed with canvas and foam wrapped around a metal armature and painted skin colour depicts our African creativity. Other wide-ranging landmarks and cultural symbols indicating Cross River State's greatness should be arranged into a unified composition. The traditional king makers Obol'Opon's costume is a marvel to behold, some of the revelers and foreign participants can be made to wear these costumes or insignias representing our culture as a way of projecting our African cultural values. This will serve an excellent "examples of cultural design themes" in African architecture (Esekong et al 26).

\section{Conclusion}

This study does not preach the prohibition of interculturality. It rather emphasizes the projection of Calabar people's culture in the Carnival Calabar. In appropriating alien cultures in the Calabar Street Party, the entrenchment of African values should take preeminence. The nude dancers that performed in the 2013 version of the Calabar Carnival was bound to distort the socialization end of the event as well as transport to the global stage pseudo-African values. While appreciating the multicultural thrust of the Street Party, this study calls on its organizers to eschew alien values that generate controversy and indoctrinate young Nigerians with false values. 


\section{References}

Asigbo, Alex. "Transmutations in Masquerade Costumes And Performances: An Examination of Abuja Carnival 2010." UJAH: Unizik Journal of Arts and Humanities 13:1 (2012): 22-33. Print.

"Carnival."Encyclopædia Britannica. Encyclopæedia Britannica Ultimate Reference Suite. Chicago: Encyclopædia Britannica, 2014. Print.

Dawson. "Costuming for Carnival Clowns." 31 Oct. 2012. htttp://www.googleclowning/carnivalperformance/costume.org 24 May 2015.Web.

Esekong, Andrew and Ekpeyong, Ibok."Promoting Culture and Tourism in Nigeria through Calabar Festival and Carnival Calabar."Mediterranean Journal of Social Sciences3:3 (2012): 32-44. Print.

Esekong H. Andrew; Chris Agibe and Emmanuel Eneh, "Technical Improvisations for Carnival Float Robotics: A Study of Passion 4 Designs in Carnival Calabar (2008-2012)." Canadian Journal of Research \& Development Center of Sciences and Cultures8:2 (2014):21-32. Print.

Gasner, John. Producing the Play. New York: Holt, Rinehart and Winston, 1963. Print.

'Malaysian Court fines a Tourist 1000 Pounds" 4 May 2015. http://www.usercontentgoogletourist.ca13 June 2015.Web.

Okoye, Chukwuma. "Cannibalization as Popular Tradition in Igbo Masquerade Performance" Research in African Literatures 41:2 (2010): 19-31. Print.

Utoh-Ezeajugh, Tracie. "Promoting Minority Cultures through Costume and Make-up: Sam Ukala'sBreak a Boil in Production."Theatre and Minority Rights: Perspectives on the Niger Delta.Ed. Austin OvigueAsagba. Ibadan: Kraft, 2010. Print.

Schechner, Richard. Essays on Performance Theory.Great Britain: Routledge, 2004. 
Amaefula \& Eze-Orji: Costuming for African Values...

Umukoro, Julie. "Environment and Cultural Factors in Design: A Paradigmatic Approach to Stage Costuming in Indigenous Nigerian Drama." Trends in Theory and Practice of Theatre in Nigeria.

Ahmed Yerima and Duro Oni (eds). Lagos: Society of Nigerian Theatre Artistes, 2008. 47-57. Print. 